\title{
GW9508 inhibits insulin secretion by activating ATP-sensitive potassium channels in rat pancreatic $\beta$-cells
}

\author{
Yu-Feng Zhao ${ }^{1,2, *}$, Li Wang ${ }^{3, *}$, Dingjun Zha ${ }^{2, *}$, Li Qiao ${ }^{2}$, Lianjun $\mathrm{Lu}^{2}$, Jun $\mathrm{Yu}^{4}$, Ping $\mathrm{Qu}^{4}$, \\ Qiang Sun', Jianhua Qiu ${ }^{2}$ and Chen Chen ${ }^{1}$ \\ ${ }^{1}$ School of Biomedical Sciences, The University of Queensland, Brisbane, Queensland 4072, Australia \\ ${ }^{2}$ Department of Otolaryngology, Xijing Hospital, Fourth Military Medical University, Xi'an 710032, China \\ ${ }^{3}$ The Second Affiliated Hospital of Medical School, Xi'an Jiao Tong University, Xi'an 710004, China \\ ${ }^{4}$ The Centre of Experiment Teaching, Fourth Military Medical University, Xi'an 710032, China \\ *(Y-F Zhao, L Wang and D Zha contributed equally to this work) \\ Correspondence \\ should be addressed \\ to C Chen or J Qiu \\ Email \\ chenchenuq@hotmail.com or \\ wangrhlz@126.com
}

\begin{abstract}
GW9508 is an agonist of G protein-coupled receptor 40 (GPR40) that is expressed in pancreatic $\beta$-cells and is reported to regulate insulin secretion. However, the effects of GW9508 on pancreatic $\beta$-cells in primary culture have not been well investigated. This study measured the acute effects of GW9508 on insulin secretion from rat pancreatic islets in primary culture, and the insulin secretion-related events such as the changes in membrane potential, ATP-sensitive potassium currents ( $\mathrm{K}_{\text {ATP }}$ currents), and intracellular $\mathrm{Ca}^{2+}$ concentrations $\left(\left[\mathrm{Ca}^{2+}\right]_{\mathrm{i}}\right)$ of rat islet $\beta$-cells were also recorded. GW9508 $(10-40 \mu \mathrm{M})$ did not influence basal insulin levels at $2 \mathrm{mM}$ glucose, but it (above $20 \mu \mathrm{M}$ ) significantly inhibited 5 and $15 \mathrm{mM}$ glucose-stimulated insulin secretion (GSIS). GW9508 did not inhibit insulin secretion stimulated by tolbutamide, the closer of $K_{\text {ATP }}$ channels. GW9508 activated K $K_{\text {ATP }}$ channels and blocked the membrane depolarization and the increase in $\left[\mathrm{Ca}^{2+}\right]_{i}$ that were stimulated by glucose. GW9508 itself stimulated a transient increase in $\left[\mathrm{Ca}^{2+}\right]_{i}$, which was fully blocked by depletion of intracellular $\mathrm{Ca}^{2+}$ stores with thapsigargin or by inhibition of phospholipase C (PLC) activity with U73122. GW9508-induced activation of $\mathrm{K}_{\text {ATP }}$ channels was only partly inhibited by U73122 treatment. In conclusion, although it stimulates a transient release of $\mathrm{Ca}^{2+}$ from intracellular $\mathrm{Ca}^{2+}$ stores via activation of PLC, GW9508 inhibits GSIS by activating $\mathrm{K}_{\text {ATP }}$ channels probably in a distal step to GPR40 activation in rat $\beta$-cells.
\end{abstract}
Key Words
- GW9508
- insulin
- K $\mathrm{K}_{\text {ATP }}$ channels
- $\beta$-cells

Journal of Molecular Endocrinology (2013) 51, 69-77

\section{Introduction}

GW9508 (3-(4-(((3-(phenyloxy)phenyl)methyl)amino) phenyl)propanoic acid) was first identified as an agonist for free fatty acid receptors (FFARs) such as G protein-coupled receptor 40 (GPR40) and GPR120 from a high-throughput screen of the GlaxoSmithKline chemical collection in 2006 (Briscoe et al. 2006). In previous reports about FFARs actions on pancreatic $\beta$-cells, FFAs were commonly used as agonists of FFARs, but the effects of GW9508 on $\beta$-cell function were seldom reported. There are only reports showing that GW9508 potentiated glucose-stimulated insulin secretion (GSIS) in insulinoma cell lines such as MIN6 cells and INS-1E cells (Briscoe et al. 2006, Yang et al. 2010). And it was shown that GW9508 does not influence insulin secretion in rat

Published by Bioscientifica Ltd. 
and mouse islets in primary culture (Briscoe et al. 2006). The detailed effects of GW9508 on the function of $\beta$-cells in primary culture are not well known.

In our previous study, we found that GW9508 activates ATP-sensitive potassium channels $\left(\mathrm{K}_{\mathrm{ATP}}\right.$ channels) on rat $\beta$-cells in primary culture (Zhao et al. 2008). The $K_{\text {ATP }}$ channel is a key controller to $\beta$-cell excitability and GSIS. It is known that pancreatic $\beta$-cells metabolize glucose to generate ATP from ADP, and the increased ATP:ADP ratio closes $\mathrm{K}_{\mathrm{ATP}}$ channels and leads to membrane depolarization and a concomitant rise in the levels of intracellular $\mathrm{Ca}^{2+}$ concentration $\left(\left[\mathrm{Ca}^{2+}\right]_{\mathrm{i}}\right)$ and insulin secretion (Ashcroft et al. 1994, Rorsman 1997, Drews et al. 2010, Rorsman et al. 2011). In the present study, we further investigated the effects of GW9508 on insulin secretion, $\mathrm{K}_{\mathrm{ATP}}$ channels, and $\left[\mathrm{Ca}^{2+}\right]_{\mathrm{i}}$ levels in primary rat islets and $\beta$-cells. It was found that GW9508 activates $\mathrm{K}_{\mathrm{ATP}}$ channels and inhibits GSIS.

\section{Materials and methods}

\section{Materials}

GW9508 was obtained from GlaxoSmithKline and Sigma. Histopaque-1077, Dispase, collagenase (type V), DNase I, BSA, RPMI-1640, thapsigargin, tolbutamide, and all reagents for bath solution and pipette solutions were purchased from Sigma. U73122 was obtained from Calbiochem (San Diego, CA, USA). Fura-2/AM was purchased from Invitrogen. FCS, HEPES, and penicillin/ streptomycin were obtained from Gibco. QIAamp DNA Investigator kits were obtained from Qiagen and the Qubit dsDNA HS assay kits were purchased from Invitrogen.

\section{Preparation and culture of rat pancreatic $\beta$-cells}

Sprague Dawley rats (8-10 weeks old) were purchased from the Animal House of The University of Queensland (UQ). The animal experiment was reviewed and approved by the Animal Care and Use Committee of UQ. Pancreatic islets were isolated from 10- to 12-week-old male Sprague Dawley rats as described previously (Zhao et al. 2008). Briefly, rats were killed and the pancreas was inflated by injecting $10 \mathrm{ml}$ collagenase solution into it through the bile duct. The collagenase solution was composed of $0.5 \mathrm{mg} / \mathrm{ml}$ collagenase, $0.1 \mathrm{mg} / \mathrm{ml}$ DNase I, and $1 \mathrm{mg} / \mathrm{ml}$ BSA in Hank's Balanced Salt Solution (HBSS). The pancreas were collected and digested at $37^{\circ} \mathrm{C}$ for $30 \mathrm{~min}$ in stationary state and then they were dispersed by shaking. The islets were separated by Histopaque-1077 density gradient centrifugation and collected under microscope.
Insulin assay was done using the isolated islets. For singlecell recording, the islets were dispersed into single cells by digestion with dispase solution. Dispase solution was composed of $1 \mathrm{mg} / \mathrm{ml}$ dispase, $0.1 \mathrm{mg} / \mathrm{ml}$ DNase I, and $1 \mathrm{mg} / \mathrm{ml} \mathrm{BSA}$ in $\mathrm{Ca}^{2+}$-free HBSS. The islet cells were plated into $35 \mathrm{~mm}$ dishes or onto glass coverslips coated with $0.01 \%$ poly-L-lysine for electrophysiological recording and $\left[\mathrm{Ca}^{2+}\right]_{\mathrm{i}}$ measurement respectively. The islet cells were cultured at $37^{\circ} \mathrm{C}$ in RPMI-1640 medium at $7 \mathrm{mM}$ glucose supplemented with $10 \%$ heat-inactivated FCS, $100 \mathrm{IU} / \mathrm{ml}$ penicillin, and $100 \mu \mathrm{g} / \mathrm{ml}$ streptomycin in a humidified atmosphere of $95 \%$ air and $5 \% \mathrm{CO}_{2}$. The culture medium was changed every 2 days. The cells were used for the experiments during days 3-6 in culture.

\section{Insulin secretion assay}

After culture overnight, the islets were washed twice with cold incubating solution and then separated into 48-well plates with 20 islets per well in $0.5 \mathrm{ml}$ incubating solution. The samples were randomly separated into different groups with eight samples per group. To observe the dose effects of GW9508, the incubating solution was collected after incubating with different treatments for $1 \mathrm{~h}$ at stationary state. To observe the effects of GW9508 on the first and second phases of GSIS, 200 islets per sample were put into perfusion chamber and perfused at a speed of $0.1 \mathrm{ml} / \mathrm{min}$ under the control of a peristaltic pump. Each experiment began after a 20-min equilibrium period of perfusion with perfusion solution containing $2 \mathrm{mM}$ glucose. Then the perfusion solution was collected every $5 \mathrm{~min}$. After being perfused at $2 \mathrm{mM}$ glucose to get the basal insulin secretion, the islets were exposed to $15 \mathrm{mM}$ glucose for $60 \mathrm{~min}$ and then washed with $2 \mathrm{mM}$ glucose. GW9508 was put into the perfusion solution $10 \mathrm{~min}$ before the exposure to $15 \mathrm{mM}$ glucose. The perfusion and incubating solution was composed of the following $(\mathrm{mM})$ : $140 \mathrm{NaCl}, 4.7 \mathrm{KCl}, 2.6 \mathrm{CaCl}_{2}, 1.2 \mathrm{MgSO}_{4}, 1 \mathrm{NaHCO}_{3}$, $1.2 \mathrm{Na}_{2} \mathrm{HPO}_{4}, 2$ glucose, and 5 HEPES ( $\mathrm{pH}=7.4$ with $\mathrm{NaOH}$ ). Insulin levels in the incubating solution were assayed by insulin ELISA kit as indicated by the kit instructions (DSL Laboratory, Webster, TX, USA). In brief, samples were pipetted into an ELISA 96-well plates in duplicate. The anti-insulin conjugate antibodies were then added, and the plates were incubated on a plate shaker at 700 r.p.m. for $2 \mathrm{~h}$ at room temperature. Then the plates were washed thoroughly and 3,3',5,5'-tetramethylbenzidine substrate solution was added and incubated for $15 \mathrm{~min}$ at room temperature in the dark. Stop buffer was added and then the absorbance was measured at $450 \mathrm{nM}$

Published by Bioscientifica Ltd. 


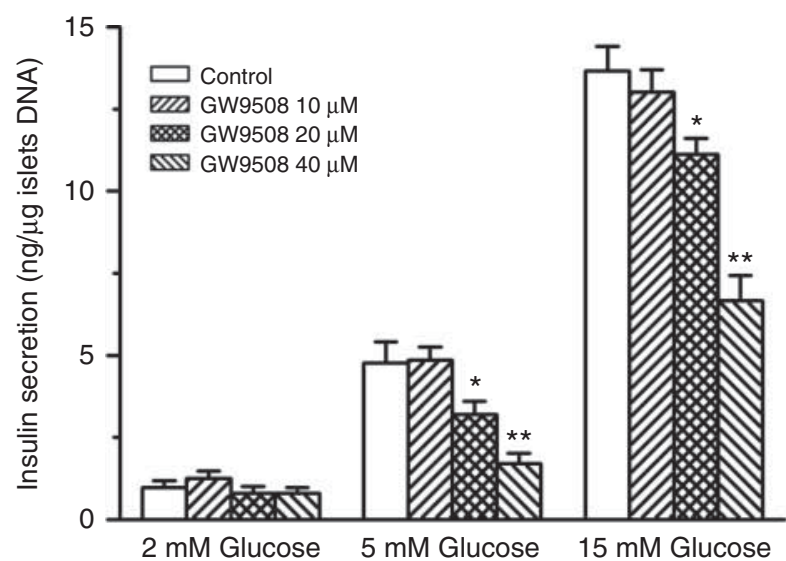

Figure 1

Effects of GW9508 on glucose-stimulated insulin secretion. Glucose at 5 and $15 \mathrm{mM}$ significantly stimulated insulin secretion compared with $2 \mathrm{mM}$ glucose. GW9508 at 20 and $40 \mu \mathrm{M}$ but not at $10 \mu \mathrm{M}$ significantly inhibited insulin secretion stimulated by 5 and $15 \mathrm{mM}$ glucose. GW9508 did not influence insulin secretion under $2 \mathrm{mM}$ glucose $(* P<0.05$ and $* * P<0.01$ vs control at same glucose levels, $n=8$ ).

with a MultiSkan ELISA plate reader. At the end of the collection of perfusion solution and the incubating solution, the islets in each sample were centrifuged and the suspension solution was removed. Total DNA from the samples was extracted using QIAamp DNA Investigator kits and was quantified using Qubit dsDNA HS assay kits with Qubit 2.0 Fluorometer as indicated by the kit instructions. The insulin level was rectified by the total DNA quantity for each sample.

\section{Electrophysiological recording in single rat $\beta$-cells}

Recordings were made using perforated whole-cell patch clamp configuration. Electrodes were pulled by a Sutter P-87 microelectrode puller from borosilicate micropipettes and had an initial input resistance of 3-5 M . All recordings were performed using the Axopatch 200A amplifier (Axon Instrument, Union City, CA, USA). The bath solution for membrane potential recording and $\mathrm{K}_{\mathrm{ATP}}$ current recording was same to the insulin assay. The pipette solution for membrane potential and $\mathrm{K}_{\mathrm{ATP}}$ current recording was composed of the following $(\mathrm{mM}): 76 \mathrm{~K}_{2} \mathrm{SO}_{4}$, $10 \mathrm{KCl}, 10 \mathrm{NaCl}, 8 \mathrm{MgSO}_{4}$, and 20 HEPES ( $\mathrm{pH}=7.3$ with $\mathrm{KOH})$. Membrane perforation was achieved by nystatin (final concentration $0.24 \mathrm{mg} / \mathrm{ml}$ in pipette solution). After formation of a high-resistance seal, the voltage in the pipette was held at $-80 \mathrm{mV}$. The series resistance reaching lower than $30 \mathrm{M} \Omega$ was considered as full access to the cell interior. The whole-cell capacitance and series resistance were well compensated and then the membrane potential or $\mathrm{K}_{\mathrm{ATP}}$ current was recorded using different protocols. Membrane potential was recorded under current-clamp mode using Axoscope 8 program, as the current was held at $0 \mathrm{pA} . \mathrm{K}_{\mathrm{ATP}}$ current was recorded under voltage-clamp mode using Clampex 8 program. The cells were held at $-80 \mathrm{mV}$, and a trial of sweeps was obtained by clamping from -130 to $-30 \mathrm{mV}$ at intervals of $1 \mathrm{~s}$ with $20 \mathrm{mV}$ increments and a duration of $300 \mathrm{~ms}$ each step. Pancreatic $\beta$-cells were identified by cell size and cell membrane capacitance. The mean capacitance of $\beta$ - and $\alpha$-cells are $5.5 \pm 0.3$ and $2.8 \pm 0.1 \mathrm{pF}$ respectively (Gopel et al. 2000, Leung et al. 2005). For this study, the cells whose wholecell capacitances were above $6 \mathrm{pF}$ were recorded and the data were used for analysis. Experiments were performed at room temperature.

\section{Measurement of $\left[\mathrm{Ca}^{2+}\right]_{i}$ in single rat $\beta$-cells}

Islet cells were loaded with $1 \mu \mathrm{M}$ Fura-2/AM in RPMI-1640 medium for $30 \mathrm{~min}$ at $37^{\circ} \mathrm{C}$. Cells were subsequently rinsed with bath solution and kept for 20 min in this solution to allow full de-esterification of the dye and tranquilization of the cells. Fura- 2 in the cell was alternately excited by 340 and $380 \mathrm{~nm}$ light (100 ms exposure and 2-s cycle) under the control of DualWavelength Photometry Controller (SDR, NSW, Australia). Emission at $510 \mathrm{~nm}$ was detected by a photomultiplier tube (PMT model 77348, Oriel, Bozeman, MT, USA). The signal was transmitted into DigiData and recorded by

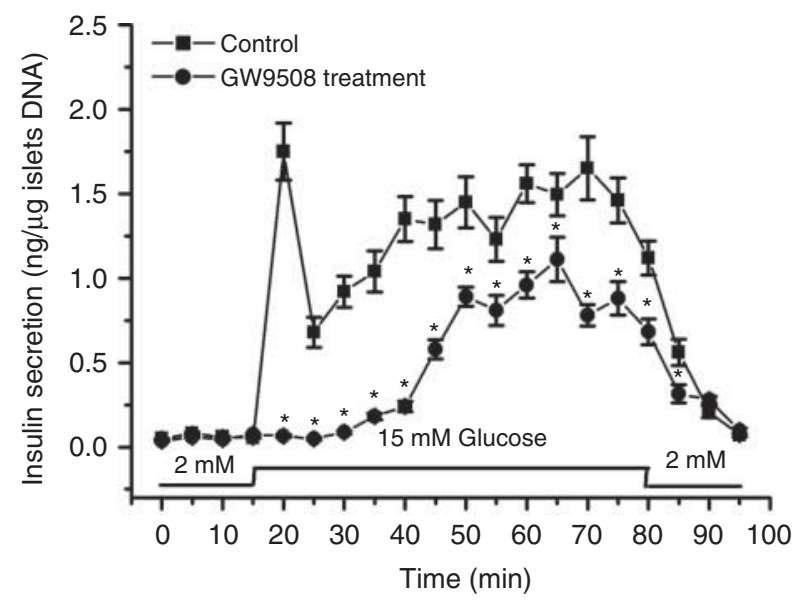

Figure 2

Effects of GW9508 on the first and second phases of glucose-stimulated insulin secretion. Insulin secretion was significantly increased in a biphasic pattern under $15 \mathrm{mM}$ glucose stimulation. GW9508 treatment $10 \mathrm{~min}$ before exposure to $15 \mathrm{mM}$ glucose completely inhibited the first phase of insulin secretion and significantly inhibited the second phase of insulin secretion ( ${ }^{*} P<0.01$ vs control at the same time point, $n=5$ ).

Published by Bioscientifica Ltd. 
Axoscope 8.2 (Axon Instrument). $\left[\mathrm{Ca}^{2+}\right]_{\mathrm{i}}$ was calculated according to the formula described by Grynkiewicz et al. (1985). $\left[\mathrm{Ca}^{2+}\right]_{\mathrm{i}}(\mathrm{nM})=K_{\mathrm{d}} \times(\mathrm{Fo} / \mathrm{Fs}) \times\left(R-R_{\min }\right) /\left(R_{\max }-R\right)$, where $K_{\mathrm{d}}$, the Fura- 2 disassociation constant $(225 \mathrm{nM})$; Fo, the $380 \mathrm{~nm}$ fluorescence in the absence of $\mathrm{Ca}^{2+}$; Fs, the $380 \mathrm{~nm}$ fluorescence with saturating $\mathrm{Ca}^{2+} ; R$, the $340: 380 \mathrm{~nm}$ fluorescence ratio; $R_{\max }$, the $340: 380 \mathrm{~nm}$ ratio with saturating $\mathrm{Ca}^{2+}$; and $R_{\min }$, the $340: 380 \mathrm{~nm}$ ratio in the absence of $\mathrm{Ca}^{2+}$. Fo/Fs, $R_{\max }$, and $R_{\min }$ were determined in the recorded cells. Briefly, the cells were permeabilized by $20 \mu \mathrm{M}$ ionomycin for $10 \mathrm{~min}$ to allow sufficient extracellular $\mathrm{Ca}^{2+}$ entry and the resulting 340:380 nm ratio is $R_{\max }$. After a steady value of $R_{\max }$ had been obtained, the $R_{\min }$ value was determined by chelating $\mathrm{Ca}^{2+}$ with $8 \mathrm{mM}$ EGTA. Cells were constantly perfused at a rate of $3 \mathrm{ml} / \mathrm{min}$. Experimental reagents were dissolved in the bath solution just before the recordings and delivered through the perfusion. The bath solution used for $\left[\mathrm{Ca}^{2+}\right]_{\mathrm{i}}$ measurements was the same as that used for the insulin assay.

\section{Statistical analysis}

The data are represented as mean \pm s.E.M. for each group. One-way ANOVA was used to analyse the statistical significance between different groups. $P<0.05$ was taken as the minimum level of statistical significance.

\section{Results}

\section{GW9508 dose dependently inhibited GSIS from rat islets}

Glucose significantly stimulated insulin secretion from rat pancreatic islets at 5 and $15 \mathrm{mM}$ concentrations during 1-h incubation compared with the basal level of $2 \mathrm{mM}$ glucose. GW9508 did not significantly influence insulin secretion at $2 \mathrm{mM}$ glucose. However, it dose dependently inhibited GSIS during 1-h incubation. GW9508 at $10 \mu \mathrm{M}$ did not influence insulin secretion at either 5 or $15 \mathrm{mM}$ glucose levels. At $5 \mathrm{mM}$ glucose, GW9508 at 20 and $40 \mu \mathrm{M}$ significantly inhibited insulin secretion 33 and $64 \%$ respectively $(4.77 \pm 0.65 \mathrm{ng} / \mu \mathrm{g}$ islets DNA in control; $3.2 \pm 0.39 \mathrm{ng} / \mu \mathrm{g}$ islets DNA at $20 \mu \mathrm{M}$ GW9508, $P<0.05$ vs control, $n=8 ; 1.71 \pm 0.31 \mathrm{ng} / \mu \mathrm{g}$ islets DNA at $40 \mu \mathrm{M}$ GW9508, $P<0.01$ vs control, $n=8$ ). At $15 \mathrm{mM}$ glucose, GW9508 at 20 and $40 \mu \mathrm{M}$ significantly inhibited insulin secretion 19 and $51 \%$ respectively $(13.66 \pm 0.74 \mathrm{ng} / \mu \mathrm{g}$ islets DNA in control; $11.11 \pm 0.49 \mathrm{ng} / \mu \mathrm{g}$ islets DNA at $20 \mu \mathrm{M}$ GW9508, $P<0.05$ vs control, $n=8 ; 6.67$ $\pm 0.76 \mathrm{ng} / \mu \mathrm{g}$ islets DNA at $40 \mu \mathrm{M}$ GW9508, $P<0.01$ vs control, $n=8$; Fig. 1). Glucose stimulated two phases of insulin secretion in rat islets as shown by the perfusion experiment. When GW9508 was given $10 \mathrm{~min}$ before the exposure to $15 \mathrm{mM}$ glucose, GW9508 $(40 \mu \mathrm{M})$ completely inhibited the first phase of GSIS. The second phase of GSIS was also significantly inhibited by GW9508, and the inhibitory ratio was about 51\% (Fig. 2). GW9508 at 20 and $40 \mu \mathrm{M}$ could not inhibit insulin secretion that was stimulated by $0.1 \mathrm{mM}$ tolbutamide at $15 \mathrm{mM}$ glucose during 1-h incubation (Fig. 3).

\section{GW9508 induced hyperpolarization and activated $\mathrm{K}_{\text {ATP }}$ channels in rat $\beta$-cells}

The resting membrane potential of rat $\beta$-cells was $-48 \pm 2 \mathrm{mV}$ at $5 \mathrm{mM}$ glucose and was significantly hyperpolarized to $-66 \pm 2 \mathrm{mV}$ by $40 \mu \mathrm{M}$ GW9508 $(P<0.01, n=8)$. The cells recovered from the hyperpolarization fully in $5 \mathrm{~min}$ after washout of GW9508 (Fig. 4A and B). GW9508 $(40 \mu \mathrm{M})$ immediately increased $\mathrm{K}_{\mathrm{ATP}}$ currents from $-4 \pm 0.7$ to $-16 \pm 2 \mathrm{pA} / \mathrm{pF}$ at $-130 \mathrm{mV}$ $(P<0.01, n=8)$. The current recovered completely to $-4 \pm 0.5 \mathrm{pA} / \mathrm{pF}, 5 \mathrm{~min}$ after washout of GW9508 (Fig. 4C). Tolbutamide decreased $\mathrm{K}_{\mathrm{ATP}}$ current from $-4 \pm 0.5$ to $-2 \pm 0.3 \mathrm{pA} / \mathrm{pF}$ at $-130 \mathrm{mV}(P<0.01, n=5)$. GW9508 $(40 \mu \mathrm{M})$, up to $10 \mathrm{~min}$, did not affect this current in the presence of tolbutamide (Fig. 4D). The doseresponses of GW9508 on membrane potential and $\mathrm{K}_{\mathrm{ATP}}$ currents were shown in Fig. $4 \mathrm{E}$ and F. At $5 \mathrm{mM}$ glucose, GW9508 at $10 \mu \mathrm{M}$ did not affect the membrane potential and $\mathrm{K}_{\mathrm{ATP}}$ currents, and GW9508 at 20 and $40 \mu \mathrm{M}$ significantly induced hyperpolarization of membrane potential and increase in $\mathrm{K}_{\mathrm{ATP}}$ currents dose dependently.

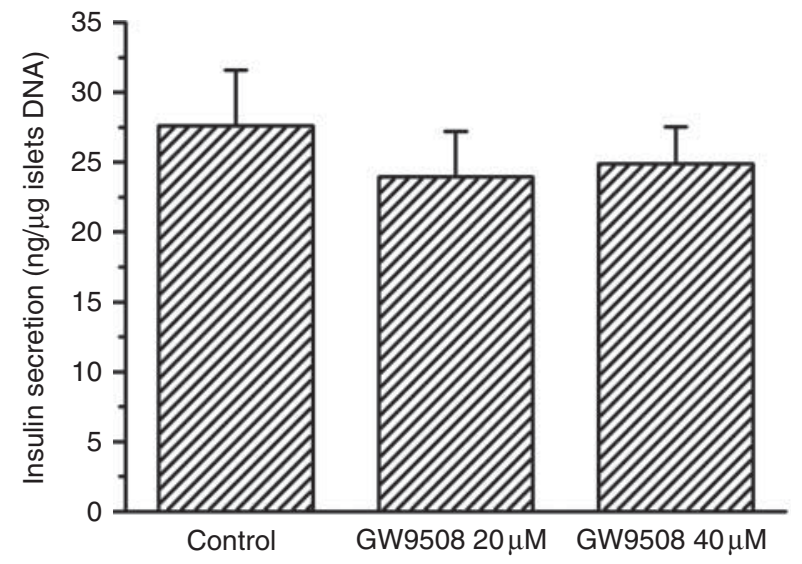

\section{Figure 3}

Effects of GW9508 on tolbutamide-stimulated insulin secretion. $0.1 \mathrm{mM}$ tolbutamide stimulated high levels of insulin secretion, and GW9508 at 20 and $40 \mu \mathrm{M}$ could not inhibit tolbutamide-stimulated insulin secretion.

Published by Bioscientifica Ltd 


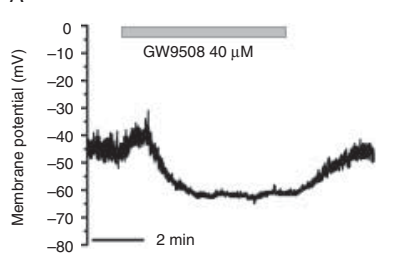

B
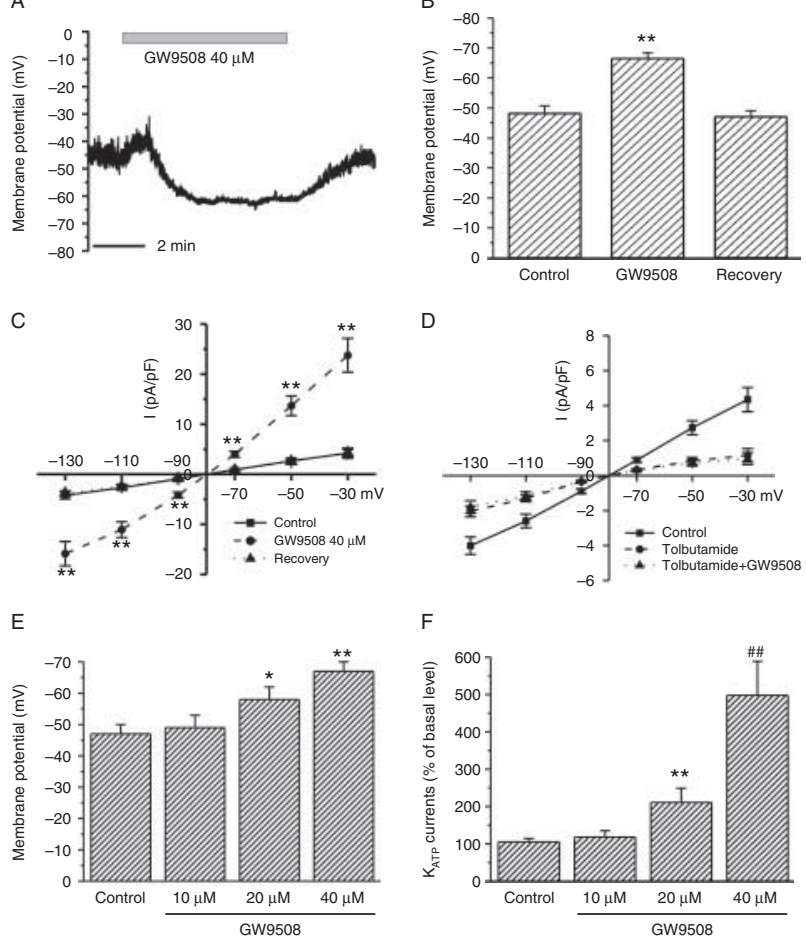
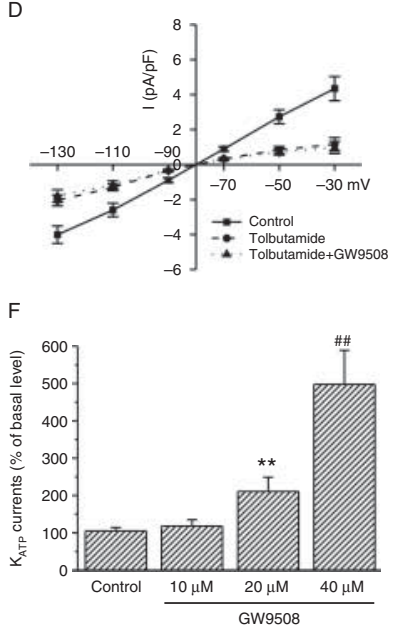

Figure 4

Effects of GW9508 on K induced hyperpolarization of membrane potential at $5 \mathrm{mM}$ glucose with a full recovery. (B) The statistical analysis of the membrane potential ( $* * P<0.01$ vs control, $n=8$ ). (C) GW9508 significantly increased $K_{\text {ATP }}$ current with full recovery after removal of GW9508 ( ${ }^{*} P<0.01$ vs control at same voltage level, $n=8$ ). (D) $0.1 \mathrm{mM}$ tolbutamide significantly reduced $\mathrm{K}_{\text {ATP }}$ current, and GW9508 could not increase the current after addition of tolbutamide. (E) GW9508 dose dependently stimulated hyperpolarization of membrane potential ( $* P<0.05$ and $* * P<0.01$ vs control, $n=5$ ). (F) GW9508 dose dependently increased $K_{\text {ATP }}$ currents ( $* * P<0.01$ vs control and ${ }^{\# \# P}<0.01$ vs control and $20 \mu \mathrm{M}$ GW9508, $n=5$ ).

Rat pancreatic $\beta$-cells depolarized and generated action potentials when the membrane potential reached about $-40 \mathrm{mV}$ in response to $15 \mathrm{mM}$ glucose, and similar responses were repetitively observed after glucose stimulation (Fig. 5A). The resting membrane potential of rat $\beta$-cells was significantly depolarized by $15 \mathrm{mM}$ glucose (Fig. $5 \mathrm{~B},-47 \pm 3$ vs $-28 \pm 7, P<0.05, n=6$ ). GW9508 $(40 \mu \mathrm{M})$ acutely induced hyperpolarization of membrane potential, and $15 \mathrm{mM}$ glucose could not induce depolarization in the presence of GW9508. Addition of $0.1 \mathrm{mM}$ tolbutamide, however, evoked depolarization of membrane potential in the presence of GW9508 (Fig. 5C). The statistical result of the membrane potential before and after GW9058 is shown in Fig. 5D.

\section{GW9508 inhibited glucose-stimulated increase in $\left[\mathrm{Ca}^{2+}\right]_{i}$ in rat $\beta$-cells}

The resting $\left[\mathrm{Ca}^{2+}\right]_{\mathrm{i}}$ level in $\beta$-cells was low at $3 \mathrm{mM}$ glucose, but it significantly increased after glucose stimulation. Glucose repetitively induced increase in $\left[\mathrm{Ca}^{2+}\right]_{i}$ in rat $\beta$-cells (Fig. 6A). The second increase in $\left[\mathrm{Ca}^{2+}\right]_{i}$ was analysed and the $\left[\mathrm{Ca}^{2+}\right]_{\mathrm{i}}$ levels were shown in Fig. 6B $(15 \pm 2$ vs $115 \pm 13 \mathrm{nM}, P<0.01, n=7)$. GW9508 $(40 \mu \mathrm{M})$ treatment completely blocked $15 \mathrm{mM}$ glucose-stimulated increase in $\left[\mathrm{Ca}^{2+}\right]_{\mathrm{i}}$ but not $0.1 \mathrm{mM}$ tolbutamide-stimulated increase in $\left[\mathrm{Ca}^{2+}\right]_{i}$ in rat $\beta$-cells (Fig. 6C). The $\left[\mathrm{Ca}^{2+}\right]_{i}$ levels in the second stimulation were analysed and shown in Fig. $6 \mathrm{D}$ (18 $\pm 3 \mathrm{nM}$ at basal level, $20 \pm 2 \mathrm{nM}$ after $15 \mathrm{mM}$ glucose, $P>0.5$ vs basal level; $126 \pm 17 \mathrm{nM}$ after tolbutamide, $P<0.01$ vs basal level, $n=7$ ).

\section{GW9508 stimulated increase in $\left[\mathrm{Ca}^{2+}\right]_{i}$ by mobilizing calcium release in rat $\beta$-cells}

GW9508 itself stimulated a transient increase in $\left[\mathrm{Ca}^{2+}\right]_{\mathrm{i}}$ in rat $\beta$-cells (Fig. 7A). Removal of extracellular $\mathrm{Ca}^{2+}$ did not eliminate the GW9508-stimulated increase (Fig. 7B). Pretreatment of the cells with thapsigargin $(1 \mu \mathrm{M}$ for $30 \mathrm{~min})$ totally eliminated the GW9508-stimulated $\left[\mathrm{Ca}^{2+}\right]_{\mathrm{i}}$ increase (Fig. 7C). The mean $\left[\mathrm{Ca}^{2+}\right]_{\mathrm{i}}$ changes $\left(\Delta\left[\mathrm{Ca}^{2+}\right]_{\mathrm{i}}\right.$, the mean $\left[\mathrm{Ca}^{2+}\right]_{\mathrm{i}}$ levels in 3 min after GW9508 stimulation subtracting basal levels of $\left[\mathrm{Ca}^{2+}\right]_{\mathrm{i}}$ ) are shown in Fig. 7D $(P<0.01$ vs control in thapsigargin group, $n=8)$.

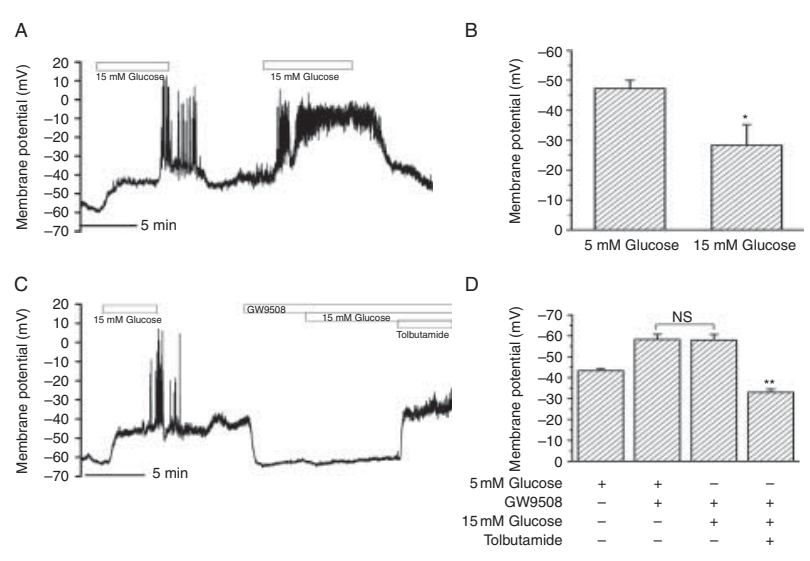

Figure 5

Effects of GW9508 on glucose-induced depolarization of $\beta$-cells. (A) The membrane potential of rat pancreatic $\beta$-cells depolarized with generation of action potentials in response to $15 \mathrm{mM}$ glucose repetitively. (B) The statistical analysis of the membrane potential in the second stimulation with glucose ( ${ }^{*}<0.05, n=6$ ). (C) GW9508 blocked $15 \mathrm{mM}$ glucose-induced depolarization but not tolbutamide-stimulated depolarization.

(D) The statistical analysis of the membrane potential in the second time treatment by GW9508, glucose, and tolbutamide ( $* * P<0.01$ vs other three groups, $n=6$ ).

Published by Bioscientifica Ltd. 
A
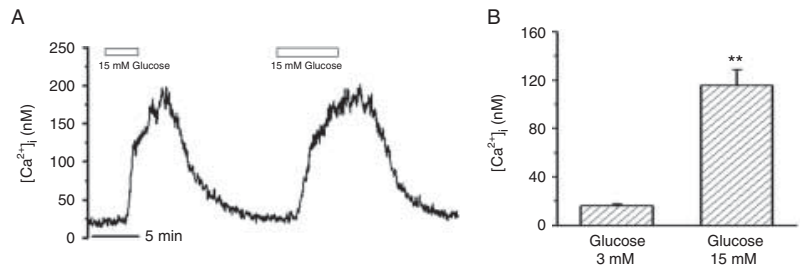

C

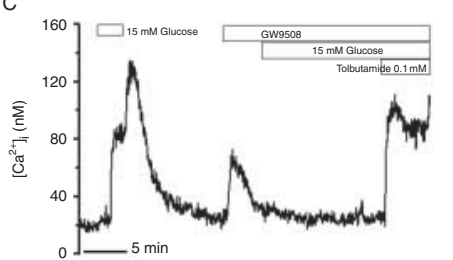

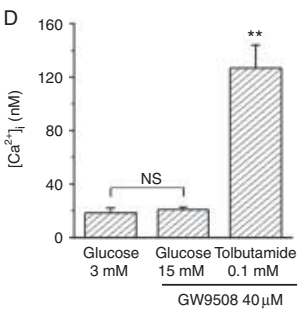

Figure 6

Effects of GW9508 on glucose-induced increase in $\left[\mathrm{Ca}^{2+}\right]_{i}$ in rat $\beta$-cells. (A) $15 \mathrm{mM}$ glucose induced the increase in $\left[\mathrm{Ca}^{2+}\right]_{i}$ in rat $\beta$-cells. (B) The statistical analysis of the maximal levels of $\left[\mathrm{Ca}^{2+}\right]_{i}$ stimulated by glucose $(* * P<0.01$ vs $3 \mathrm{mM}$ glucose, $n=7$ ). (C) GW9508 blocked glucose-induced increase in $\left[\mathrm{Ca}^{2+}\right]_{i}$ but not tolbutamide-stimulated increase in $\left[\mathrm{Ca}^{2+}\right]_{i}$ in rat $\beta$-cells. (D) The statistical analysis of the maximal levels of $\left[\mathrm{Ca}^{2+}\right]_{i}$ stimulated by glucose and tolbutamide (no significant difference between 3 and $15 \mathrm{mM}$ glucose; ${ }^{*} P<0.01$ vs 3 and $15 \mathrm{mM}$ glucose, $n=7$ ).

\section{Effects of U73122 treatment on GW9508-induced acti- vation of $\mathrm{K}_{\mathrm{ATP}}$ channels and increase in $\left[\mathrm{Ca}^{2+}\right]_{i}$ in $\beta$-cells}

Activation of phospholipase C (PLC) and the subsequent production of inositol triphosphate (IP3) is one of the signalling pathways for ligand-stimulated calcium release from intracellular calcium stores (Briscoe et al. 2003, Fujiwara et al. 2005). We tested the effect of PLC blockade by U73122 on GW9508-induced activation of $\mathrm{K}_{\mathrm{ATP}}$ channels and increase in $\left[\mathrm{Ca}^{2+}\right]_{i}$ in $\beta$-cells. The $\mathrm{K}_{\mathrm{ATP}}$ currents were activated to $567 \pm 85 \%$ of basal levels by $40 \mu \mathrm{M}$ GW9508. After U73122 treatment $(10 \mu \mathrm{M}$ for $10 \mathrm{~min}$ ), the $\mathrm{K}_{\mathrm{ATP}}$ currents were activated to $250 \pm 51 \%$ of basal levels by $40 \mu \mathrm{M}$ GW9508 (Fig. $8 \mathrm{~A}, P<0.01$ vs control, $n=8)$. The $\left[\mathrm{Ca}^{2+}\right]_{\mathrm{i}}$ levels increased significantly by GW9508 stimulation, and this increase was totally blocked by U73122 treatment $(10 \mu \mathrm{M}$ for $10 \mathrm{~min})$. The mean level of GW9508-stimulated $\left[\mathrm{Ca}^{2+}\right]_{\mathrm{i}}$ was $287 \pm 65 \%$ of the control, which decreased to $108 \pm 12 \%$ of the control in U73122 group (Fig. $8 \mathrm{~B}, P<0.01$ vs nonU73122 control group, $n=8$ ).

\section{Discussion}

GW9508 was first identified as FFAR agonist to activate GPR40 and GPR120 (Briscoe et al. 2006, Sum et al. 2007, Tikhonova et al. 2007). In the present study, we found that GW9508 inhibits GSIS by activating $\mathrm{K}_{\mathrm{ATP}}$ channels in rat pancreatic $\beta$-cells, which is supported by the results of insulin secretion assay, electrophysiological recording, and $\left[\mathrm{Ca}^{2+}\right]_{\mathrm{i}}$ recording.

Glucose stimulates insulin secretion in a biphasic manner that is mediated by two different signalling pathways, the $\mathrm{K}_{\mathrm{ATP}}$ channel-dependent pathway and $\mathrm{K}_{\text {ATP }}$ channel-independent pathway (Gembal et al. 1992, Komatsu et al. 1997, Straub et al. 1998, Henquin 2000, Aizawa et al. 2002). ATP derived from glucose oxidation closes $\mathrm{K}_{\mathrm{ATP}}$ channels and leads to depolarization of membrane potential and subsequent activation of voltage-gated $\mathrm{Ca}^{2+}$ channels $\left(\mathrm{Ca}^{2+}{ }_{(\mathrm{v})}\right.$ channels). The increase in $\left[\mathrm{Ca}^{2+}\right]_{\mathrm{i}}$ following the influx of $\mathrm{Ca}^{2+}$ via $\mathrm{Ca}^{2+}$ (v) channels triggers the first phase of insulin secretion in $\mathrm{K}_{\mathrm{ATP}}$ channel-dependent manner (Rorsman 1997). Augmentation of $\mathrm{Ca}^{2+}$-triggered insulin secretion by $\mathrm{K}_{\mathrm{ATP}}$ channels independent of signals that follow glucose metabolism takes part in the second phase of insulin secretion (Straub et al. 1998, Straub \& Sharp 2002). GW9508 completely inhibited the first phase of GSIS, and it partially inhibited the second phase of GSIS. It supports that GW9508 mainly inhibits the $\mathrm{K}_{\mathrm{ATP}}$ dependent pathway but not $\mathrm{K}_{\mathrm{ATP}}$-independent pathway.

Pancreatic $\mathrm{K}_{\mathrm{ATP}}$ channels are formed by two different types of subunits, the Kir6.2 inwardly rectifying potassium channels and sulphonylurea receptor subunit SUR1. Pancreatic $\mathrm{K}_{\mathrm{ATP}}$ channels are specifically blocked by sulphonylurea such as tolbutamide. Although GW9508
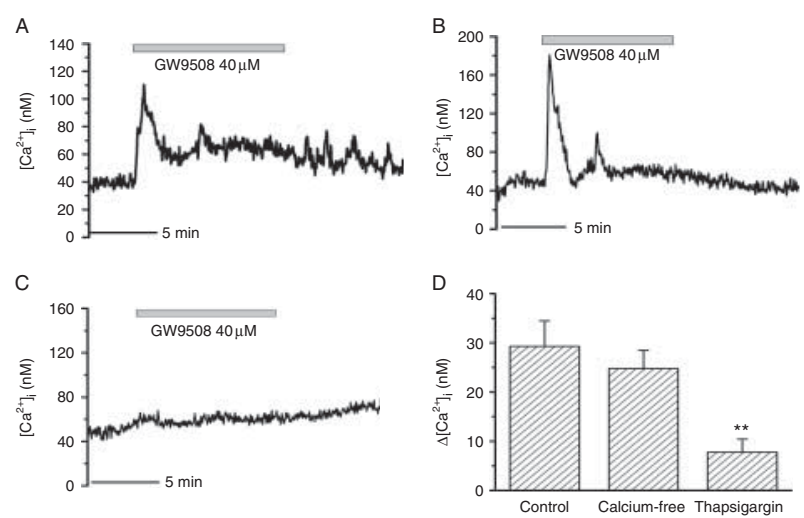

Figure 7

Effects of GW9508 on $\left[\mathrm{Ca}^{2+}\right]_{i}$ levels in rat $\beta$-cells. (A) GW9508 stimulated transient increase in $\left[\mathrm{Ca}^{2+}\right]_{i}$ in rat $\beta$-cells in normal solution. (B) Removal of extracellular $\mathrm{Ca}^{2+}$ did not eliminate GW9508-stimulated increase in $\left[\mathrm{Ca}^{2+}\right]_{\mathrm{i}}$. (C) Thapsigargin treatment $(1 \mu \mathrm{M}$ for $30 \mathrm{~min})$ fully eliminated GW9508-stimulated increase in $\left[\mathrm{Ca}^{2+}\right]_{i}$. (D) Analysis of the mean $\left[\mathrm{Ca}^{2+}\right]_{\mathrm{i}}$ changes ( $* * P<0.01$ vs control, $n=8$ ).

Published by Bioscientifica Ltd. 
A

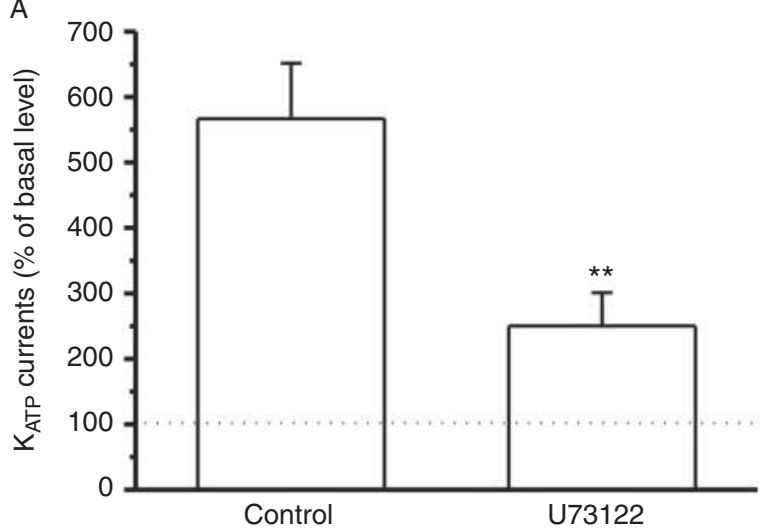

B

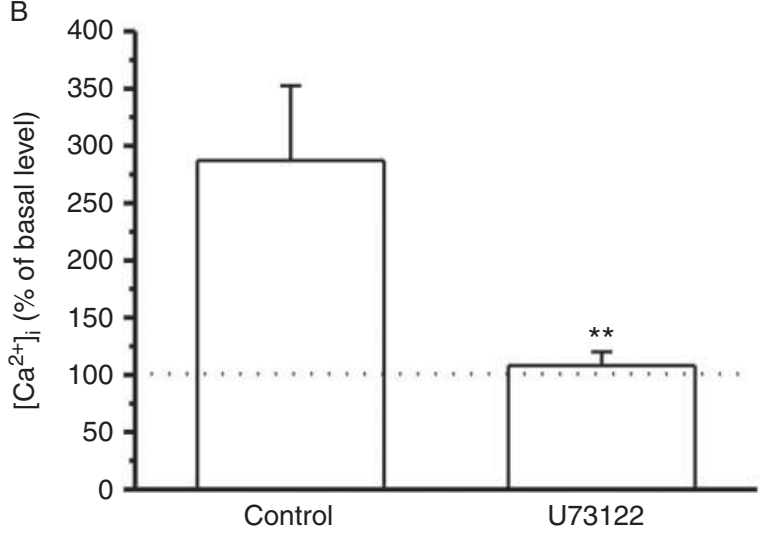

Figure 8

Effects of PLC inhibition on GW9508-induced activation of $\mathrm{K}_{\text {ATP }}$ channels and increase in $\left[\mathrm{Ca}^{2+}\right]_{\mathrm{i}}$ in rat $\beta$-cells. (A) U73122 treatment $(10 \mu \mathrm{M}$ for $10 \mathrm{~min}$ ) partly inhibited the activation of $\mathrm{K}_{\text {ATP }}$ currents induced by GW9508 ( $* * P<0.01$ vs control, $n=8$ ). (B) U73122 treatment completely blocked the increase in $\left[\mathrm{Ca}^{2+}\right]_{i}$ stimulated by GW9508 (**P<0.01 vs control, $\left.n=8\right)$. The dotted lines indicate the $100 \%$ of basal levels.

inhibited GSIS, it could not inhibit tolbutamidestimulated insulin secretion. This supports that GW9508 inhibits GSIS by opening $\mathrm{K}_{\mathrm{ATP}}$ channels. The subsequent electrophysiological recording showed that GW9508 induced hyperpolarization of membrane potential and increase in $\mathrm{K}_{\mathrm{ATP}}$ currents, giving strong evidence that GW9508 activated $\mathrm{K}_{\mathrm{ATP}}$ channels. $\left[\mathrm{Ca}^{2+}\right]_{\mathrm{i}}$ recording further confirmed that GW9508 inhibited GSIS by opening $\mathrm{K}_{\mathrm{ATP}}$ channels because the increase in $\left[\mathrm{Ca}^{2+}\right]_{\mathrm{i}}$ stimulated by glucose but not by tolbutamide was inhibited GW9508.

Although GW9508 mobilizes intracellular calcium stores, the present study suggests that the effect is not strong enough to stimulate insulin secretion and to counteract its inhibitory effects on GSIS. GW9508stimulated increase in $\left[\mathrm{Ca}^{2+}\right]_{\mathrm{i}}$ was eliminated by depletion of intracellular endoplasmic reticulum calcium stores by thapsigargin treatment, but not by removal of extracellular calcium. It is therefore suggested that GW9508 stimulates calcium release from intracellular calcium stores. Previous reports suggested that FFAR such as GPR40 activation is linked to PLC and mobilization of intracellular calcium stores by production of IP3 (Briscoe et al. 2003, Fujiwara et al. 2005). Moreover, it has been confirmed that GPR40 activation can stimulate phosphatidylinositol hydrolysis, further supporting that the IP3 signalling pathway is employed by GPR40 (Meidute Abaraviciene et al. 2008). The present results indicate that GW9508 may activate GPR40 and subsequently stimulate calcium release from intracellular calcium stores. This is further confirmed by the observation that inhibition of PLC activity by U73122 totally blocked GW9508-stimulated increase in $\left[\mathrm{Ca}^{2+}\right]_{i}$ in rat $\beta$-cells. However, this increase in $\left[\mathrm{Ca}^{2+}\right]_{\mathrm{i}}$ is not sufficient enough to stimulate insulin secretion as there was no significant increase in insulin secretion after GW9508 stimulation at $2 \mathrm{mM}$ glucose and no augmenting effect was observed of GW9508 on tolbutamide-stimulated insulin secretion. As the increase in $\left[\mathrm{Ca}^{2+}\right]_{\mathrm{i}}$ stimulated by GW9508 is transient and comes from release of intracellular $\mathrm{Ca}^{2+}$ stores, it may not be sufficient in either a temporal or spatial manner to stimulate exocytosis of insulin granules. On the other hand, the process of exocytosis can be regulated by membrane potential, and it is indicated that depolarization can enhance exocytosis voltage dependently (Mochida et al. 1998). Hyperpolarization of the membrane potential by GW9508 may counteract the stimulatory effects of $\left[\mathrm{Ca}^{2+}\right]_{i}$ increase on exocytosis of insulin granules.

GW9508 mobilized intracellular calcium by activating PLC, but the effects of GW9508 on $\mathrm{K}_{\mathrm{ATP}}$ channels were not solely mediated by PLC. Blockade of PLC by U73122 only inhibited the activation of $\mathrm{K}_{\mathrm{ATP}}$ channels by GW9508 in part, suggesting that other signalling pathways may also be involved. It has been reported that oleic acid promotes the activation of the extracellular signal-regulated protein kinase-MAPK signalling pathway, mainly via FFAR (Zhang et al. 2007). This indicates that multiple signalling pathways are employed by FFAR. In our previous study, we also tried to clarify the signalling molecules that are involved in the activation of $\mathrm{K}_{\mathrm{ATP}}$ channels by GW9508, but it was found that neither protein kinase A nor $\mathrm{C}$ is involved in the action of GW9508 on $\mathrm{K}_{\mathrm{ATP}}$ channels (Zhao et al. 2008). Further investigation will be required to clarify the candidate signals in mediating the activation of $\mathrm{K}_{\mathrm{ATP}}$ channels by GW9508 and the involvement of FFAR.

Published by Bioscientifica Ltd. 
Previous reports mostly indicate that FFAR activation by FFAs stimulates insulin secretion (Itoh et al. 2003, Fujiwara et al. 2005, Salehi et al. 2005, Shapiro et al. 2005). While it was reported that GW9508 is an agonist of FFAR, the inhibitory effects of GW9508 on GSIS are controversial to the stimulatory effects of FFAs on insulin secretion. The discrepancy may be due to differences in species and the significant physiological difference between cell lines and islets $\beta$-cell in primary culture. Briscoe et al. (2006) did not see the stimulatory effects of $10 \mu \mathrm{M}$ GW9508 on insulin secretion in mouse or rat islets, although they observed the stimulatory effects of GW9508 on insulin secretion in MIN6 cells. On the other hand, FFAs not only act as ligands to activate FFAR but also enter cells to be metabolized. The metabolic effects of FFAs could not be fully excluded in previous reports about the stimulation of insulin secretion by FFAs through FFAR. GW9508 does not generate intracellular metabolic effects by itself upon activation of FFAR (Briscoe et al. 2006, Sum et al. 2007). The different chemical properties between FFAs and GW9508 may be one reason for the discrepancy in action on insulin secretion. Moreover, the possibility that GW9508 activates $K_{\text {ATP }}$ channels via a non-FFAR signalling pathway has not been ruled out. This possibility can be clarified by observing the effects of GW9508 on insulin secretion from islets of FFAR knockout animals such as GPR40 knockout mice. Owing to the limitation to obtaining the animal models, we at present are not able to exclude the possibility of non-FFAR effects of GW9508. However, our results suggest that it is worthy to observe the effects of GW9508 in GPR40 knockout mice, which would deepen our comprehension of the mechanism of GW9508-induced activation of $\mathrm{K}_{\mathrm{ATP}}$ channels.

In summary, the present study suggests that GW9508 is not a secretagogue for insulin secretion in rat islets. GW9508 above $20 \mu \mathrm{M}$ inhibits insulin secretion via activating $\mathrm{K}_{\mathrm{ATP}}$ channels. Although PLC is involved in the action of GW9508 on $\mathrm{K}_{\mathrm{ATP}}$ channels, the detailed signalling pathways for the effects of GW9508 needs to be further investigated.

\section{Declaration of interest}

The authors declare that there is no conflict of interest that could be perceived as prejudicing the impartiality of the research reported.

\section{Funding}

This work is supported by the grant from Australian NH and MRC and the fund from National Natural Sciences Foundation of China (no. 30971078).
Acknowledgements

The authors are grateful to GlaxoSmithKline for providing GW9508.

\section{References}

Aizawa T, Sato Y \& Komatsu M 2002 Importance of nonionic signals for glucose-induced biphasic insulin secretion. Diabetes 51 (Suppl 1) S96-S98. (doi:10.2337/diabetes.51.2007.S96)

Ashcroft FM, Proks P, Smith PA, Ammala C, Bokvist K \& Rorsman P 1994 Stimulus-secretion coupling in pancreatic $\beta$ cells. Journal of Cellular Biochemistry 55 (Suppl) 54-65. (doi:10.1002/jcb.240550007)

Briscoe CP, Tadayyon M, Andrews JL, Benson WG, Chambers JK, Eilert MM, Ellis C, Elshourbagy NA, Goetz AS, Minnick DT et al. 2003 The orphan G protein-coupled receptor GPR40 is activated by medium and long chain fatty acids. Journal of Biological Chemistry 278 11303-11311. (doi:10.1074/jbc.M211495200)

Briscoe CP, Peat AJ, McKeown SC, Corbett DF, Goetz AS, Littleton TR, McCoy DC, Kenakin TP, Andrews JL, Ammala C et al. 2006 Pharmacological regulation of insulin secretion in MIN6 cells through the fatty acid receptor GPR40: identification of agonist and antagonist small molecules. British Journal of Pharmacology 148 619-628. (doi:10.1038/sj.bjp.0706770)

Drews G, Krippeit-Drews P \& Dufer M 2010 Electrophysiology of islet cells. Advances in Experimental Medicine and Biology 654 115-163. (doi:10.1007/978-90-481-3271-3_7)

Fujiwara K, Maekawa F \& Yada T 2005 Oleic acid interacts with GPR40 to induce $\mathrm{Ca}^{2+}$ signaling in rat islet $\beta$-cells: mediation by PLC and L-type $\mathrm{Ca}^{2+}$ channel and link to insulin release. American Journal of Physiology. Endocrinology and Metabolism 289 E670-E677. (doi:10.1152/ajpendo. 00035.2005)

Gembal M, Gilon P \& Henquin JC 1992 Evidence that glucose can control insulin release independently from its action on ATP-sensitive $\mathrm{K}^{+}$channels in mouse B cells. Journal of Clinical Investigation 89 1288-1295. (doi:10.1172/JCI115714)

Gopel SO, Kanno T, Barg S \& Rorsman P 2000 Patch-clamp characterisation of somatostatin-secreting $\delta$-cells in intact mouse pancreatic islets. Journal of Physiology 528 497-507. (doi:10.1111/j.1469-7793.2000. 00497.x)

Grynkiewicz G, Poenie M \& Tsien RY 1985 A new generation of $\mathrm{Ca}^{2+}$ indicators with greatly improved fluorescence properties. Journal of Biological Chemistry 260 3440-3450.

Henquin JC 2000 Triggering and amplifying pathways of regulation of insulin secretion by glucose. Diabetes 49 1751-1760. (doi:10.2337/ diabetes.49.11.1751)

Itoh Y, Kawamata Y, Harada M, Kobayashi M, Fujii R, Fukusumi S, Ogi K, Hosoya M, Tanaka Y, Uejima $\mathrm{H}$ et al. 2003 Free fatty acids regulate insulin secretion from pancreatic $\beta$ cells through GPR40. Nature $\mathbf{4 2 2}$ 173-176. (doi:10.1038/nature01478)

Komatsu M, Schermerhorn T, Noda M, Straub SG, Aizawa T \& Sharp GW 1997 Augmentation of insulin release by glucose in the absence of extracellular $\mathrm{Ca}^{2+}$ : new insights into stimulus-secretion coupling. Diabetes 46 1928-1938. (doi:10.2337/diabetes.46.12.1928)

Leung YM, Ahmed I, Sheu L, Tsushima RG, Diamant NE, Hara M \& Gaisano HY 2005 Electrophysiological characterization of pancreatic islet cells in the mouse insulin promoter-green fluorescent protein mouse. Endocrinology 146 4766-4775. (doi:10.1210/en.2005-0803)

Meidute Abaraviciene S, Lundquist I, Galvanovskis J, Flodgren E, Olde B \& Salehi A 2008 Palmitate-induced $\beta$-cell dysfunction is associated with excessive NO production and is reversed by thiazolidinedionemediated inhibition of GPR40 transduction mechanisms. PLOS ONE 3 e2182. (doi:10.1371/journal.pone.0002182)

Mochida S, Yokoyama CT, Kim DK, Itoh K \& Catterall WA 1998 Evidence for a voltage-dependent enhancement of neurotransmitter release 
mediated via the synaptic protein interaction site of N-type $\mathrm{Ca}^{2+}$ channels. PNAS 95 14523-14528. (doi:10.1073/pnas.95.24.14523)

Rorsman P 1997 The pancreatic $\beta$-cell as a fuel sensor: an electrophysiologist's viewpoint. Diabetologia 40 487-495. (doi:10.1007/ s001250050706)

Rorsman P, Eliasson L, Kanno T, Zhang Q \& Gopel S 2011 Electrophysiology of pancreatic $\beta$-cells in intact mouse islets of Langerhans. Progress in Biophysics and Molecular Biology 107 224-235. (doi:10.1016/ j.pbiomolbio.2011.06.009)

Salehi A, Flodgren E, Nilsson NE, Jimenez-Feltstrom J, Miyazaki J, Owman C \& Olde B 2005 Free fatty acid receptor 1 (FFA(1)R/GPR40) and its involvement in fatty-acid-stimulated insulin secretion. Cell and Tissue Research 322 207-215. (doi:10.1007/s00441-005-0017-z)

Shapiro H, Shachar S, Sekler I, Hershfinkel M \& Walker MD 2005 Role of GPR40 in fatty acid action on the $\beta$ cell line INS-1E. Biochemical and Biophysical Research Communications 335 97-104. (doi:10.1016/j.bbrc. 2005.07.042)

Straub SG \& Sharp GW 2002 Glucose-stimulated signaling pathways in biphasic insulin secretion. Diabetes/Metabolism Research and Reviews 18 451-463. (doi:10.1002/dmrr.329)

Straub SG, James RF, Dunne MJ \& Sharp GW 1998 Glucose activates both K(ATP) channel-dependent and K(ATP) channel-independent signaling pathways in human islets. Diabetes $\mathbf{4 7}$ 758-763. (doi:10.2337/diabetes. 47.5.758)

http://jme.endocrinology-journals.org DOI: 10.1530/JME-13-0019
(C) 2013 Society for Endocrinology Printed in Great Britain
Sum CS, Tikhonova IG, Neumann S, Engel S, Raaka BM, Costanzi S \& Gershengorn MC 2007 Identification of residues important for agonist recognition and activation in GPR40. Journal of Biological Chemistry 282 29248-29255. (doi:10.1074/jbc.M705077200)

Tikhonova IG, Sum CS, Neumann S, Thomas CJ, Raaka BM, Costanzi S \& Gershengorn MC 2007 Bidirectional, iterative approach to the structural delineation of the functional "Chemoprint" in GPR40 for agonist recognition. Journal of Medicinal Chemistry 50 2981-2989. (doi:10.1021/jm0614782)

Yang M, Chisholm JW, Soelaiman S \& Shryock JC 2010 Sulfonylureas uncouple glucose-dependence for GPR40-mediated enhancement of insulin secretion from INS-1E cells. Molecular and Cellular Endocrinology 315 308-313. (doi:10.1016/j.mce.2009. 09.033)

Zhang Y, Xu M, Zhang S, Yan L, Yang C, Lu W, Li Y \& Cheng H 2007 The role of $\mathrm{G}$ protein-coupled receptor 40 in lipoapoptosis in mouse $\beta$-cell line NIT-1. Journal of Molecular Endocrinology 38 651-661. (doi:10.1677/JME-06-0048)

Zhao YF, Pei J \& Chen C 2008 Activation of ATP-sensitive potassium channels in rat pancreatic $\beta$-cells by linoleic acid through both intracellular metabolites and membrane receptor signalling pathway. Journal of Endocrinology 198 533-540. (doi:10.1677/ JOE-08-0105)

Received in final form 23 April 2013

Accepted 29 April 2013

Accepted Preprint published online 29 April 2013 